Supplement of

\title{
Revisiting properties and concentrations of ice-nucleating particles in the sea surface microlayer and bulk seawater in the Canadian Arctic during summer
}

Victoria E. Irish et al.

Correspondence to: Allan Bertram (bertram@chem.ubc.ca)

The copyright of individual parts of the supplement might differ from the CC BY 4.0 License. 


\section{Supplemental information}

\section{S1 Non-colligative effects of seawater on freezing temperatures}

Two $\mathrm{ml}$ of a microlayer sample stored at $-80^{\circ} \mathrm{C}$ for less than 6 months (station 4) was mixed with $2 \mathrm{ml}$ of a solution of Instant Ocean salt in ultrapure water. Instant Ocean is a commercially available sea salt replica used regularly by aquariums to mimic 5 ocean composition (Atkinson and Bingman, 1997). The microlayer sample was mixed with three different concentrations of the Instant Ocean solution $(26,55$, and $77 \mathrm{~g}$ of salt per $\mathrm{kg}$ of water) to make three salinity-altered microlayer samples. The freezing temperatures of the three salinity altered microlayer samples and the freezing temperatures of the three Instant Ocean solutions were measured and are shown in Figure S6.

10 


\begin{tabular}{|c|c|c|c|c|c|}
\hline Station & Photos & Notes & Station & Photos & Notes \\
\hline 1 & - & $\begin{array}{l}\text { Foggy. } \\
\text { Rippled sea } \\
\text { surface with a } \\
\text { small swell. } \\
\text { Beaufort scale } \\
\text { (BS) approx. } \\
3-4 \text {. Wind } \\
\text { speed } 3.8 \mathrm{~m} / \mathrm{s} \text {. }\end{array}$ & 7 & & $\begin{array}{l}\text { A lot of ice } \\
\text { and icebergs. } \\
\text { Starting to } \\
\text { spit rain. } \\
\text { Overcast. } \\
\text { Polar bears in } \\
\text { vicinity. Wind } \\
\text { speed } 0.3 \mathrm{~m} / \mathrm{s} \text {. }\end{array}$ \\
\hline 2 & 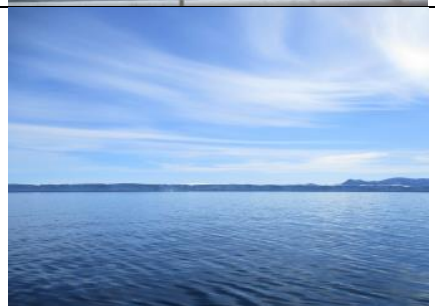 & $\begin{array}{l}\text { Sunny. Next } \\
\text { to ice island. } \\
\text { Icebergs } \\
\text { approx. } 100 \mathrm{~m} \\
\text { away. BS } \\
\text { approx. } 2 . \\
\text { Wind speed } \\
6.1 \mathrm{~m} / \mathrm{s} \text {. }\end{array}$ & 8 & & $\begin{array}{l}\text { Overcast. Ice } \\
\text { bits around. } \\
\text { BS } \sim 1 . \text { No } \\
\text { polar } \\
\text { bears...yet. } \\
\text { Wind speed } \\
3.5 \mathrm{~m} / \mathrm{s} \text {. }\end{array}$ \\
\hline 3 & 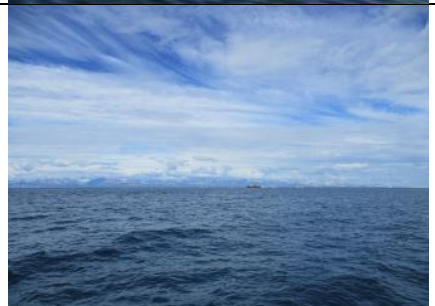 & $\begin{array}{l}\text { Partly sunny. } \\
\text { Light winds. } \\
\text { A few } \\
\text { icebergs } \\
\text { approx. } 200 \mathrm{~m} \\
\text { away. Can see } \\
\text { land. Wind } \\
\text { speed } 6.6 \mathrm{~m} / \mathrm{s} \text {. }\end{array}$ & 9 & & $\begin{array}{l}\text { Sunny, ice } \\
\text { bits, } 1 / 10^{\text {th }} \\
\text { ice. BS } 0 . \\
\text { Clouds } 1 / 9^{\text {th }} \\
\text { cirrus. Wind } \\
\text { speed } 1.3 \mathrm{~m} / \mathrm{s} \text {. }\end{array}$ \\
\hline 4 & & $\begin{array}{l}\text { Can see } \\
\text { Greenland. } \\
\text { Overcast, } \\
\text { rippled sea } \\
\text { surface and a } \\
\text { bit of a swell. } \\
\text { BS } \sim 2 \text {. Wind } \\
\text { speed } 0.7 \mathrm{~m} / \mathrm{s} \text {. }\end{array}$ & 10 & & $\begin{array}{l}\text { BS } \sim \text {, } \\
\text { sunrise, clear } \\
\text { skies, most } \\
\text { wavy } \\
\text { conditions yet. } \\
\text { Wind speed } \\
6.9 \mathrm{~m} / \mathrm{s} \text {. }\end{array}$ \\
\hline 5 & & $\begin{array}{l}\text { Sunny, slight } \\
\text { swell, rippled } \\
\text { surface. BS } \\
\sim 3 / 4 \text {. Wind } \\
\text { speed } 2.8 \mathrm{~m} / \mathrm{s} \text {. }\end{array}$ & 11 & & $\begin{array}{l}\text { BS } \sim \text {, } \\
\text { sunrise, } \\
\text { mostly } \\
\text { cloudy. Wind } \\
\text { speed } 5.6 \mathrm{~m} / \mathrm{s} \text {. }\end{array}$ \\
\hline 6 & 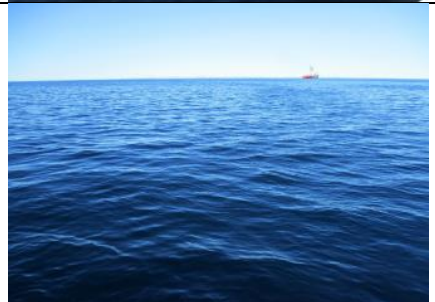 & $\begin{array}{l}\text { Sunny, rippled } \\
\text { waves. } \\
\text { Icebergs more } \\
\text { than } 2 \mathrm{miles} \\
\text { away. BS } 2 . \\
\text { Wind speed } \\
4.4 \mathrm{~m} / \mathrm{s} \text {. }\end{array}$ & & & \\
\hline
\end{tabular}

Table S1. Conditions at sampling stations. 


\begin{tabular}{|l|r|r|r|}
\hline & \multicolumn{3}{|c|}{ Bulk $\mathrm{T}_{50}$-value } \\
\hline & $\mathrm{r}$ & $\mathrm{p}$ & $\mathrm{n}$ \\
\hline $\begin{array}{l}\text { Heterotrophic bacterial } \\
\text { abundance }\end{array}$ & $\mathbf{- 0 . 5 3}$ & $\mathbf{0 . 0 4 7}$ & $\mathbf{1 1}$ \\
\hline $\begin{array}{l}\text { Total phytoplankton } \\
\text { abundance }(0.2-20 \mu \mathrm{m})\end{array}$ & 0.48 & 0.067 & 11 \\
\hline Salinity & $\mathbf{- 0 . 8 3}$ & $\mathbf{0 . 0 0 1}$ & $\mathbf{1 1}$ \\
\hline Temperature & 0.36 & 0.151 & 10 \\
\hline
\end{tabular}

Table S2. Correlations between biological and physical properties of bulk seawater and $\mathrm{T}_{50}$-values in 2016. Values in bold indicate results that are statistically significant. 


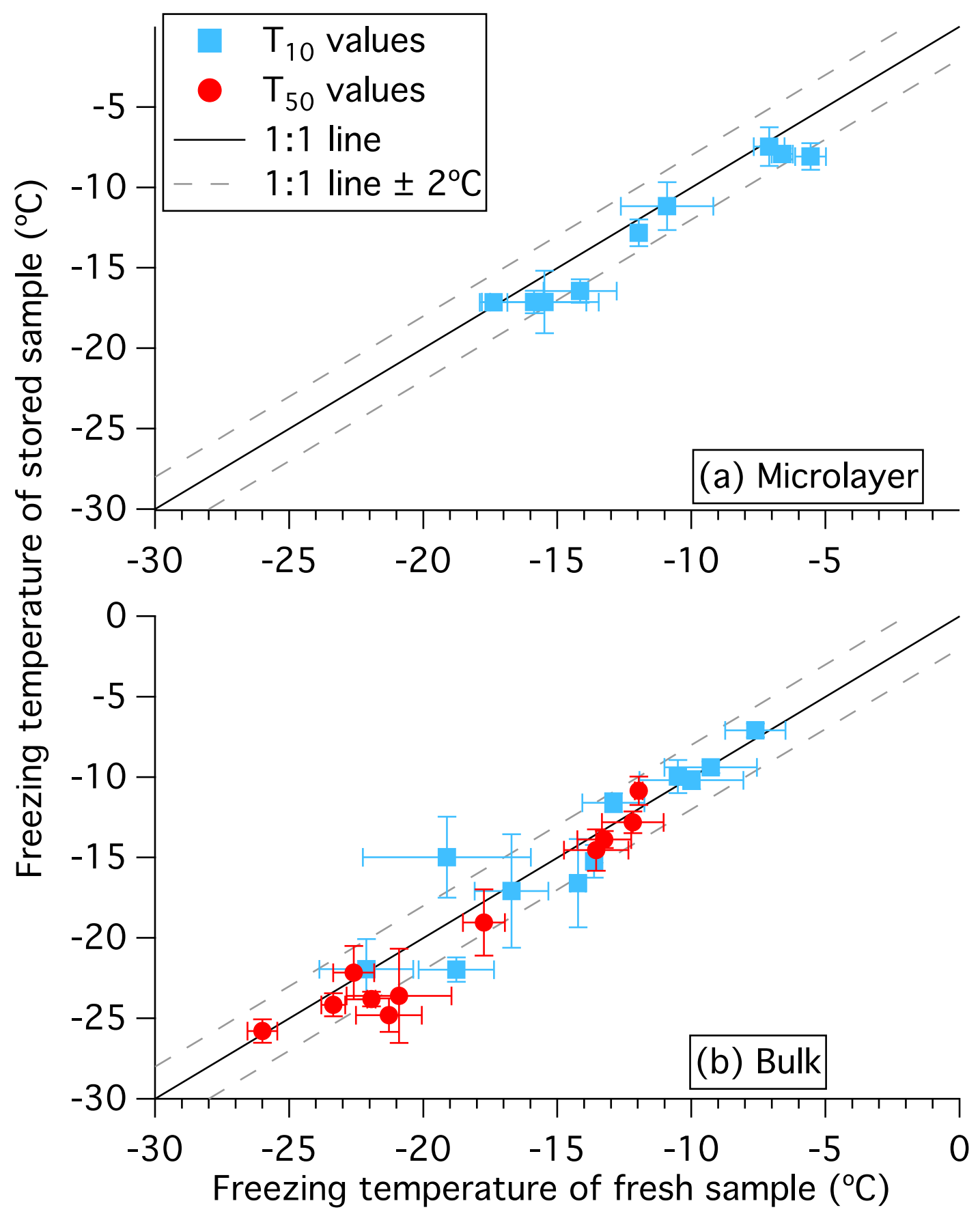

Figure S1. Plots comparing the T50-values and $\mathrm{T}_{10}$-values for duplicate fresh and stored (at $-80{ }^{\circ} \mathrm{C}$ for up to six months) samples. (a) Microlayer samples and (b) bulk seawater samples. Data points are the average $\mathrm{T}_{50}$-values and $\mathrm{T}_{10}$-values from three experiments. Error bars 5 are the $95 \%$ confidence interval for three repeat experiments. With experimental variability, all microlayer and bulk seawater samples lie within the $1: 1$ line $\pm 2{ }^{\circ} \mathrm{C}$. 


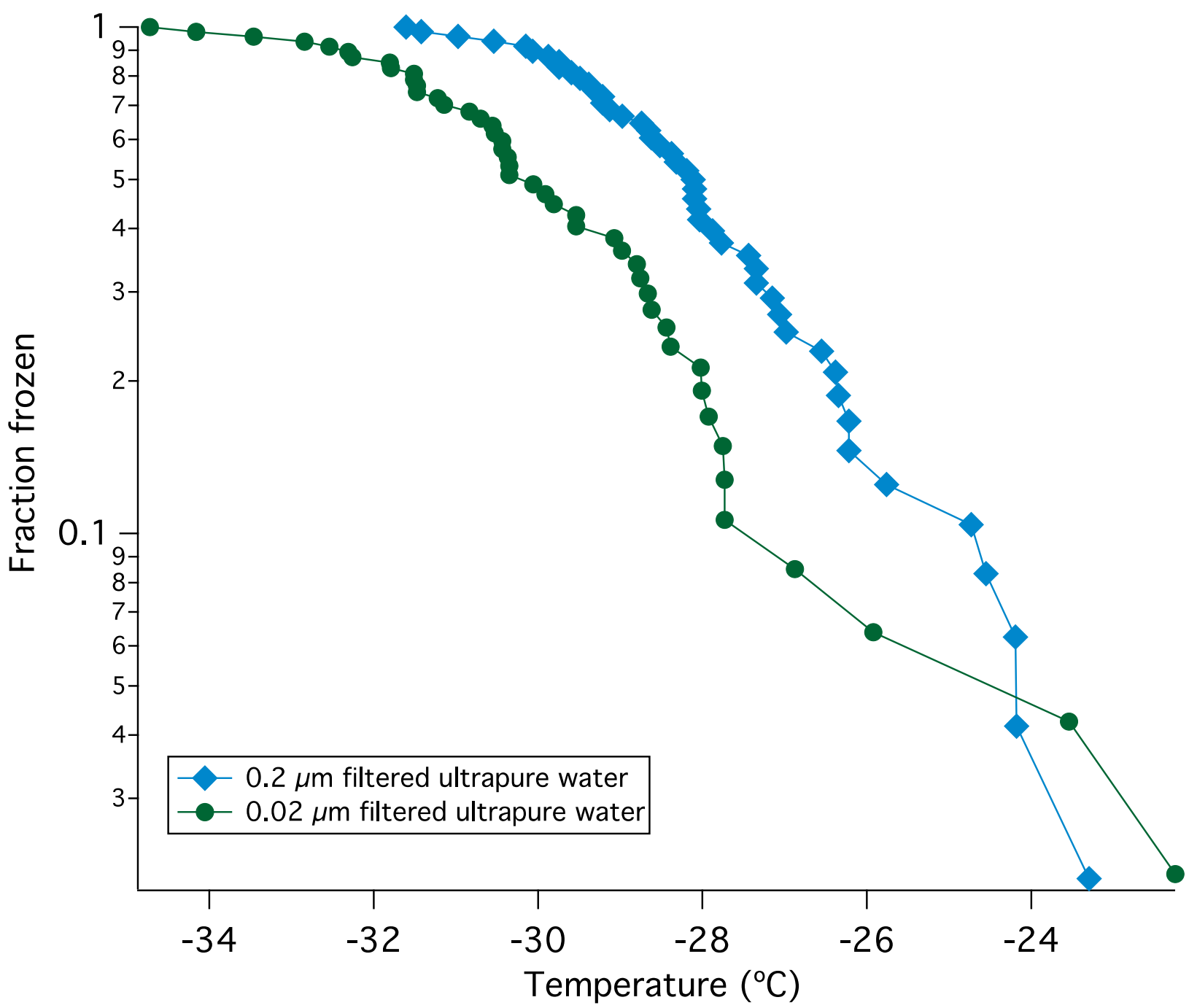

Figure S2. Plot comparing the frozen fraction curves of ultrapure water passed through filters with pore sizes of 0.2 and $0.02 \mu \mathrm{m}$. 


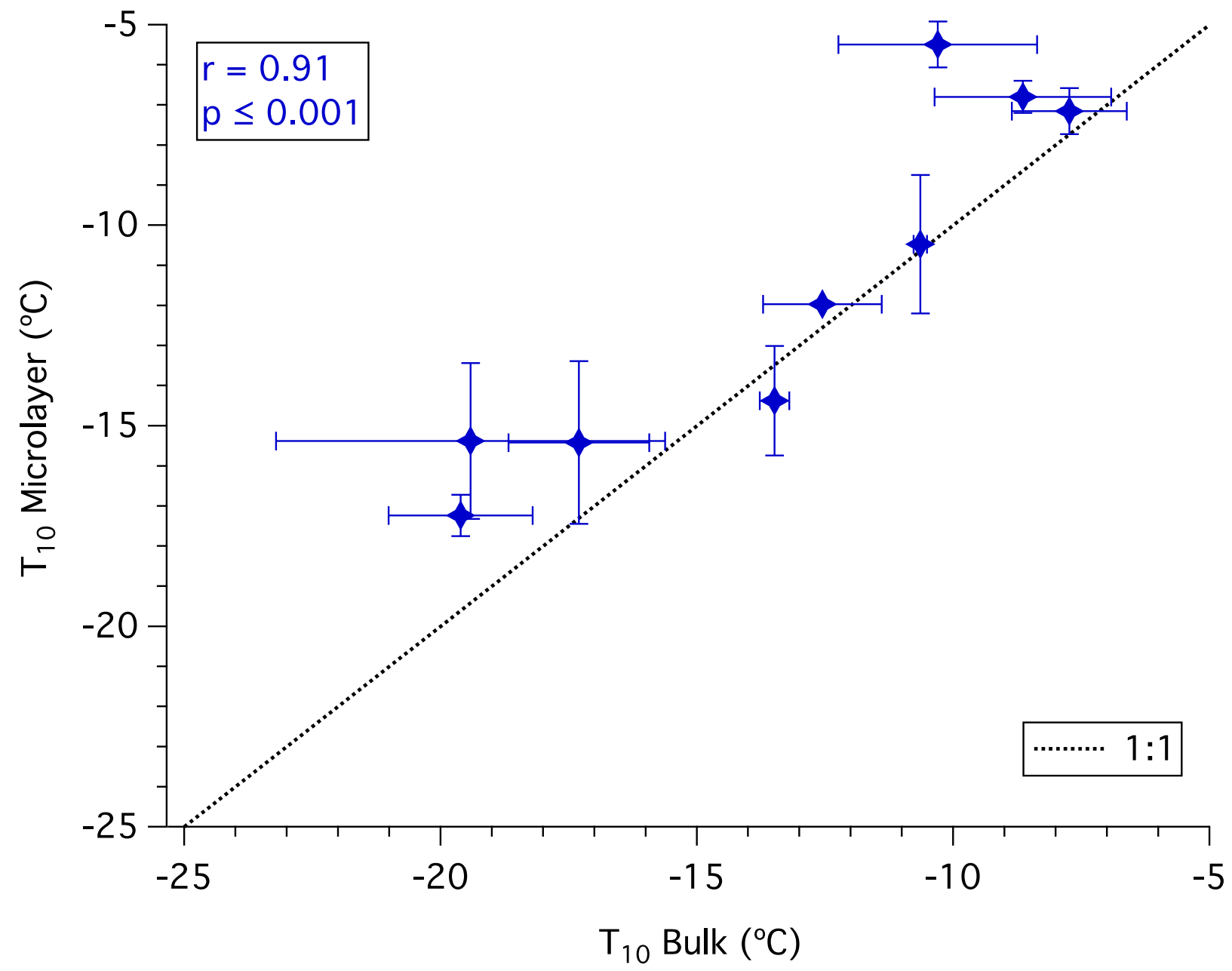

Figure S3. Relationship between $\mathrm{T}_{10}$-values for microlayer and bulk seawater samples with a 1:1 line for reference. Data points are the average $\mathrm{T}_{10}$-values from three repeat experiments. Error bars are the $95 \%$ confidence interval for three repeat experiments. Only freezing data that was at warmer temperatures than the field blanks are included. 


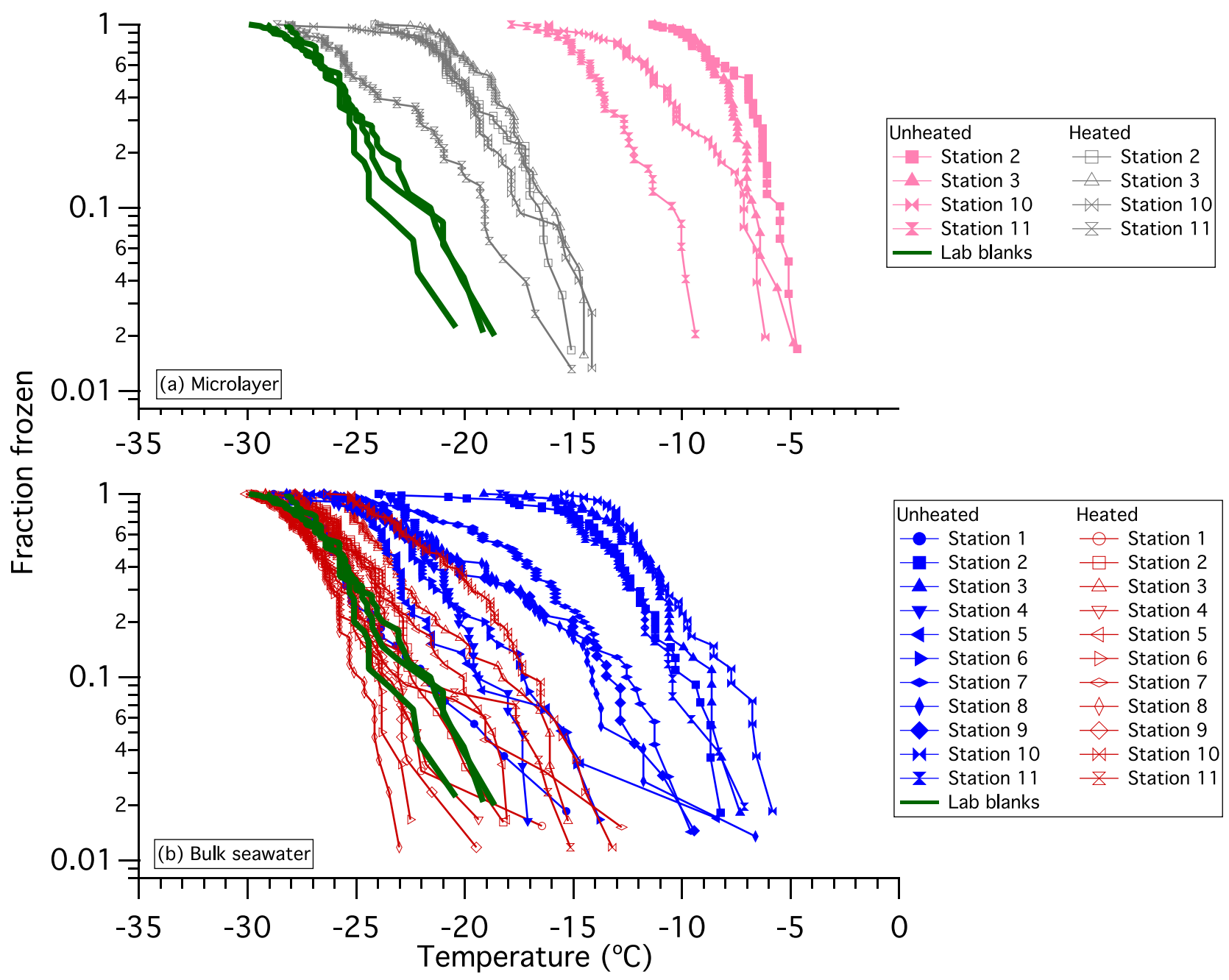

Figure S4. Effect of heating on the fraction frozen curves for unfiltered samples from (a) the microlayer and (b) bulk seawater. Each data point corresponds to one droplet freezing event. All data have been corrected for freezing point depression. 


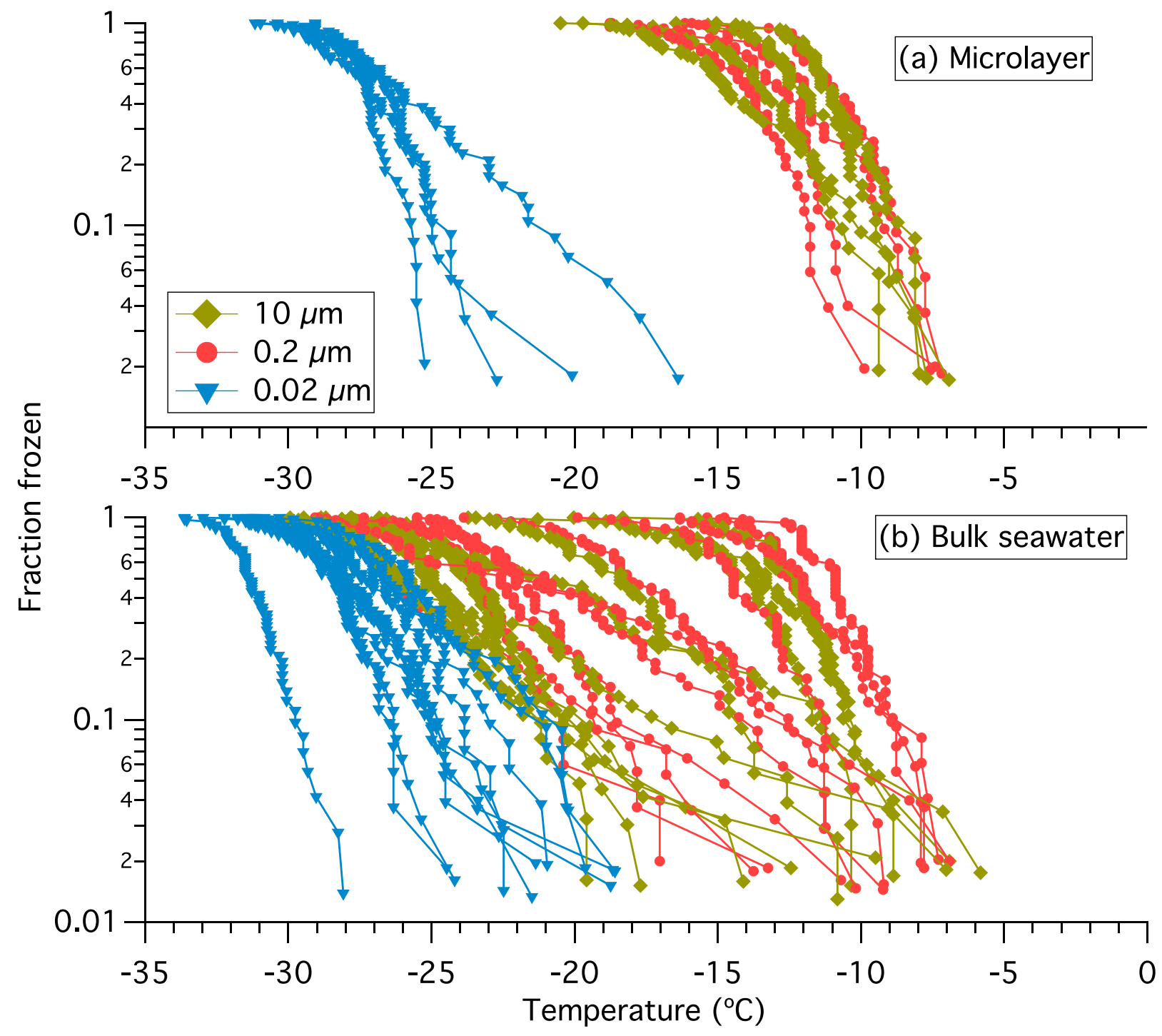

Figure S5. Fraction of droplets frozen as a function of filter pore size in (a) microlayer samples and (b) bulk seawater samples. Filter pore sizes used in the experiments were $10 \mu \mathrm{m}$ (yellow diamonds), $0.2 \mu \mathrm{m}$ (red circles) and $0.02 \mu \mathrm{m}$ (blue triangles). All data have been corrected for freezing point depression. 

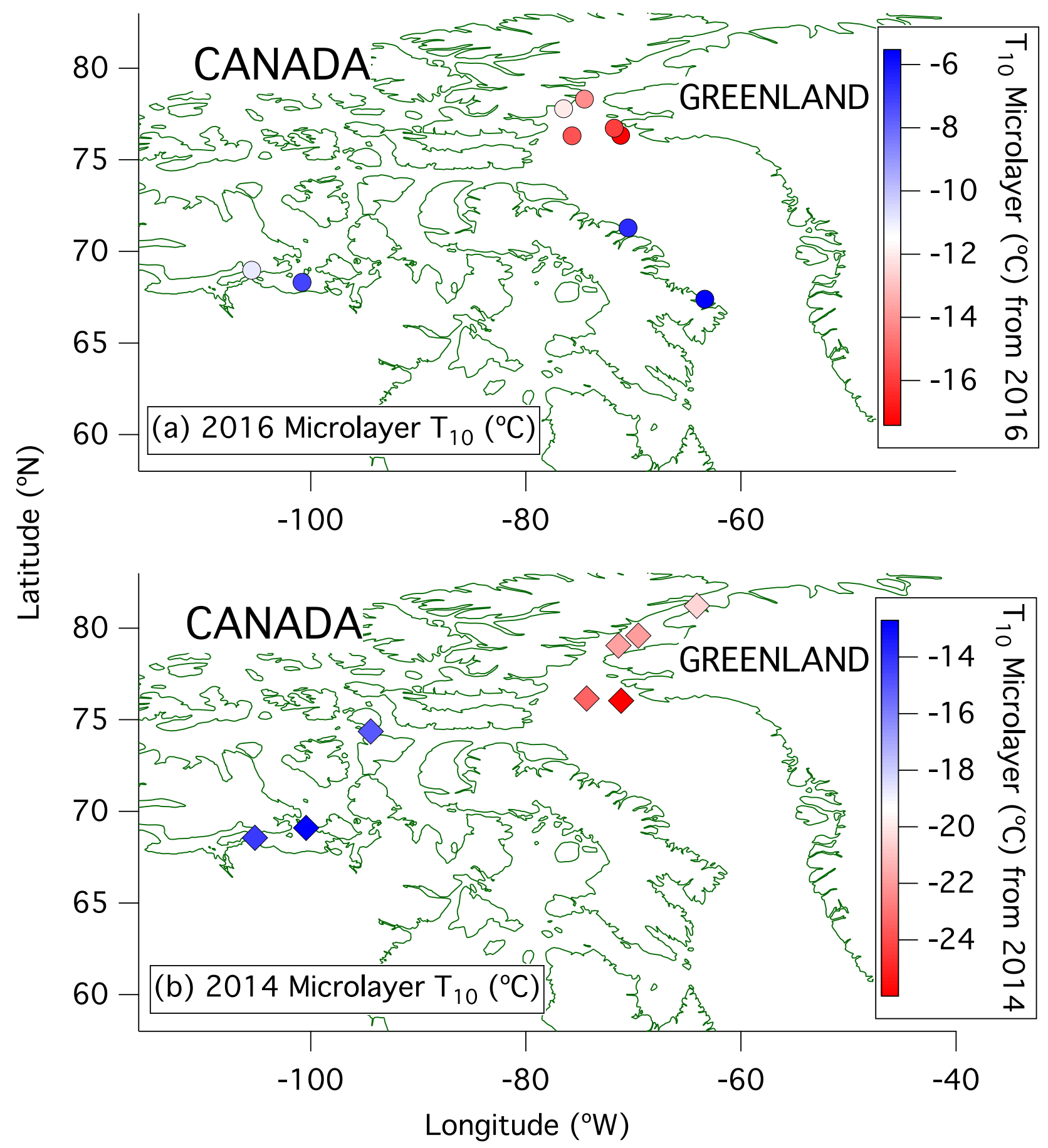

Figure S6. Spatial patterns of $\mathrm{T}_{10}$-values in (a) 2016, and (b) 2014 for the microlayer. 

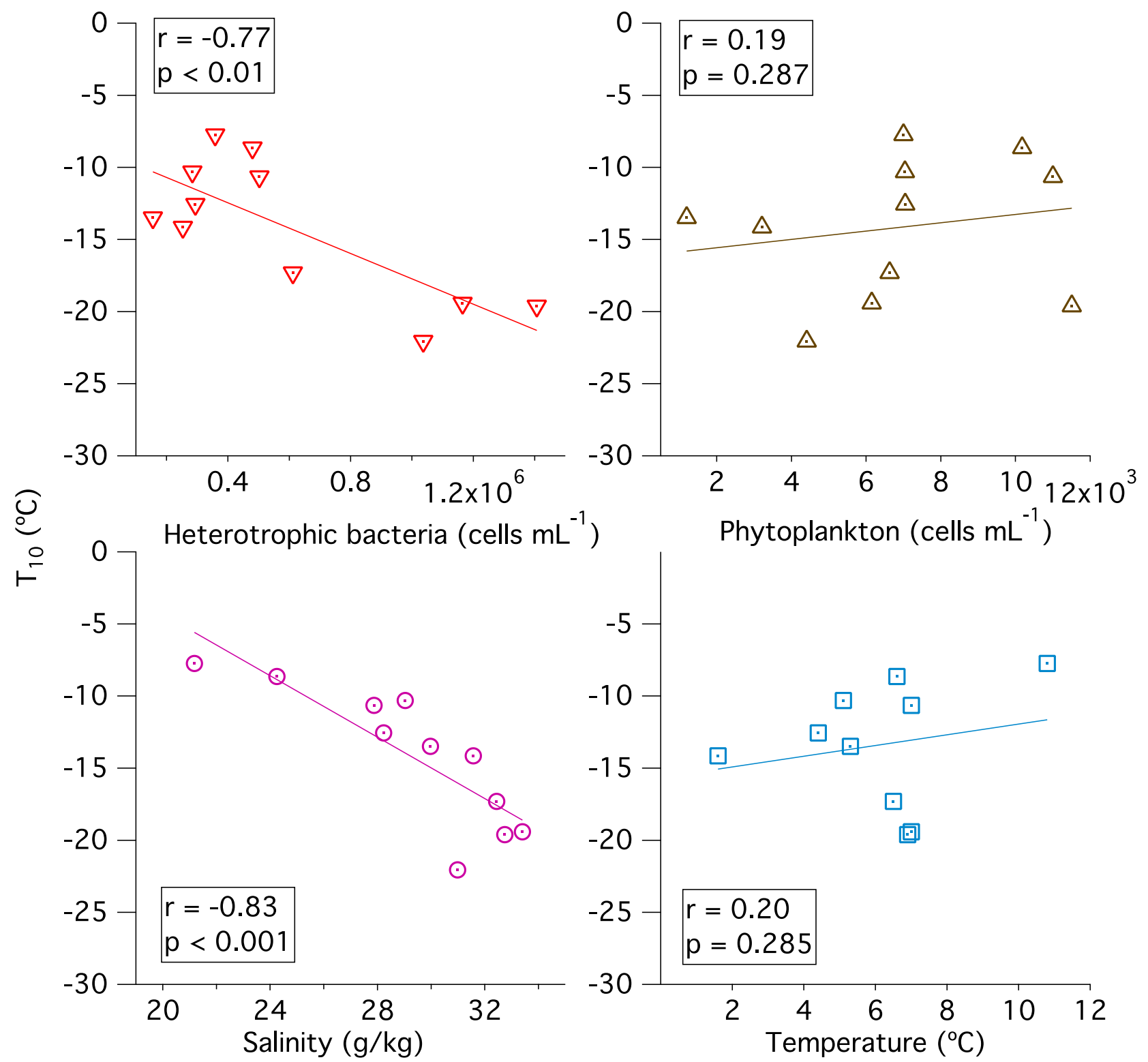

Figure S7. Relationships between $\mathrm{T}_{10}$-values, and biological or physical properties of bulk seawater during the 2016 expedition. Phytoplankton include $0.2-20 \mu \mathrm{m}$ photosynthetic eukaryotes and cyanobacteria. 


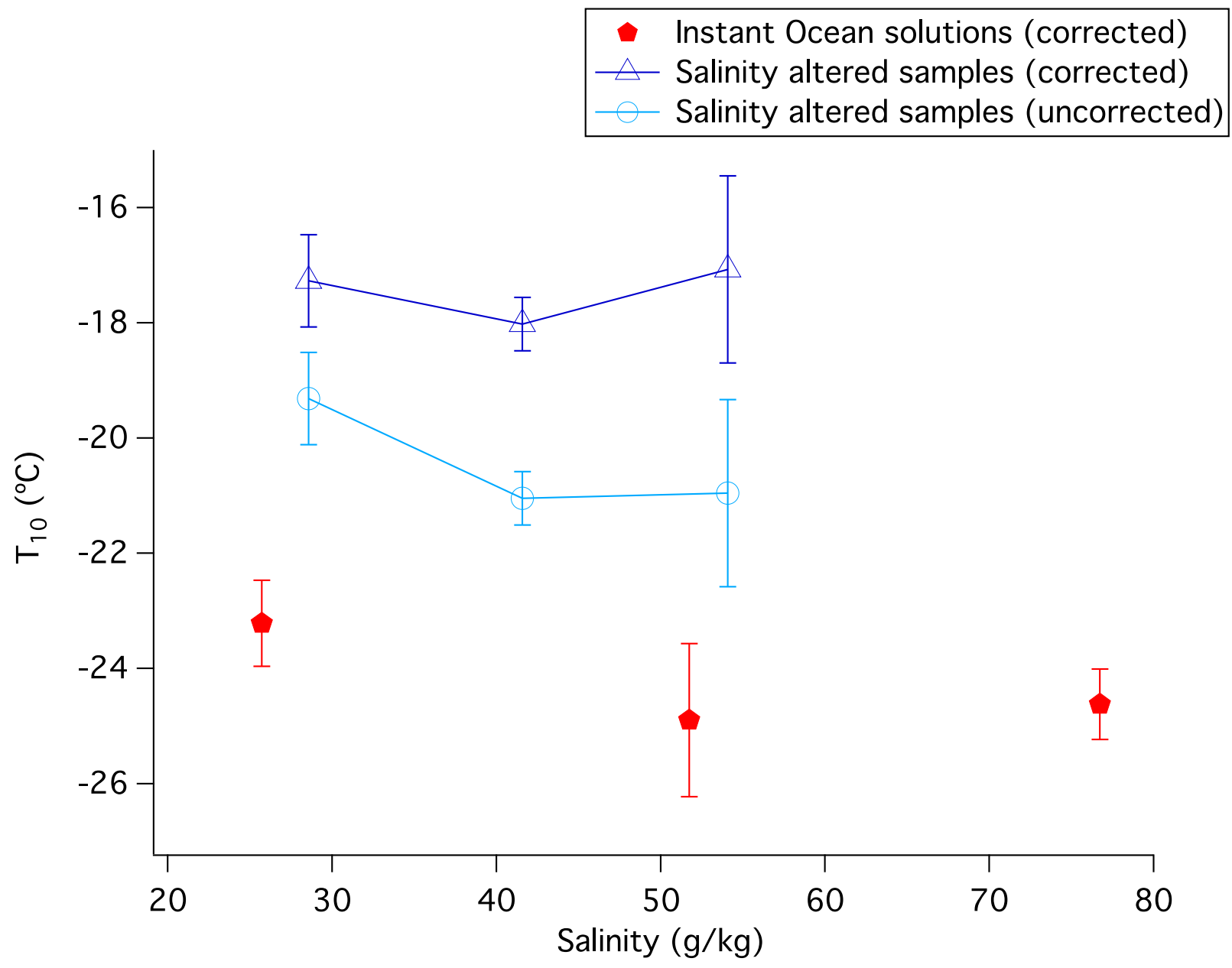

Figure S8. Plot of the $\mathrm{T}_{10}$-values of the microlayer sample from station 4 as a function of salinity. The salinity was adjusted by adding solutions of Instant Ocean in ultrapure water to the samples. Data points represent averages and error bars represent the $95 \%$ confidence 5 intervals of 3 repeat experiments. Light blue circles represent $\mathrm{T}_{10}$-values uncorrected for freezing point depression. Dark blue triangles represent $\mathrm{T}_{10}$-values after correcting for freezing point depression by the presence of salts as described in Section 2.3.3. Red pentagons represent $\mathrm{T}_{10}$-values for solutions of Instant Ocean in ultrapure water, after correcting for freezing point depression. 

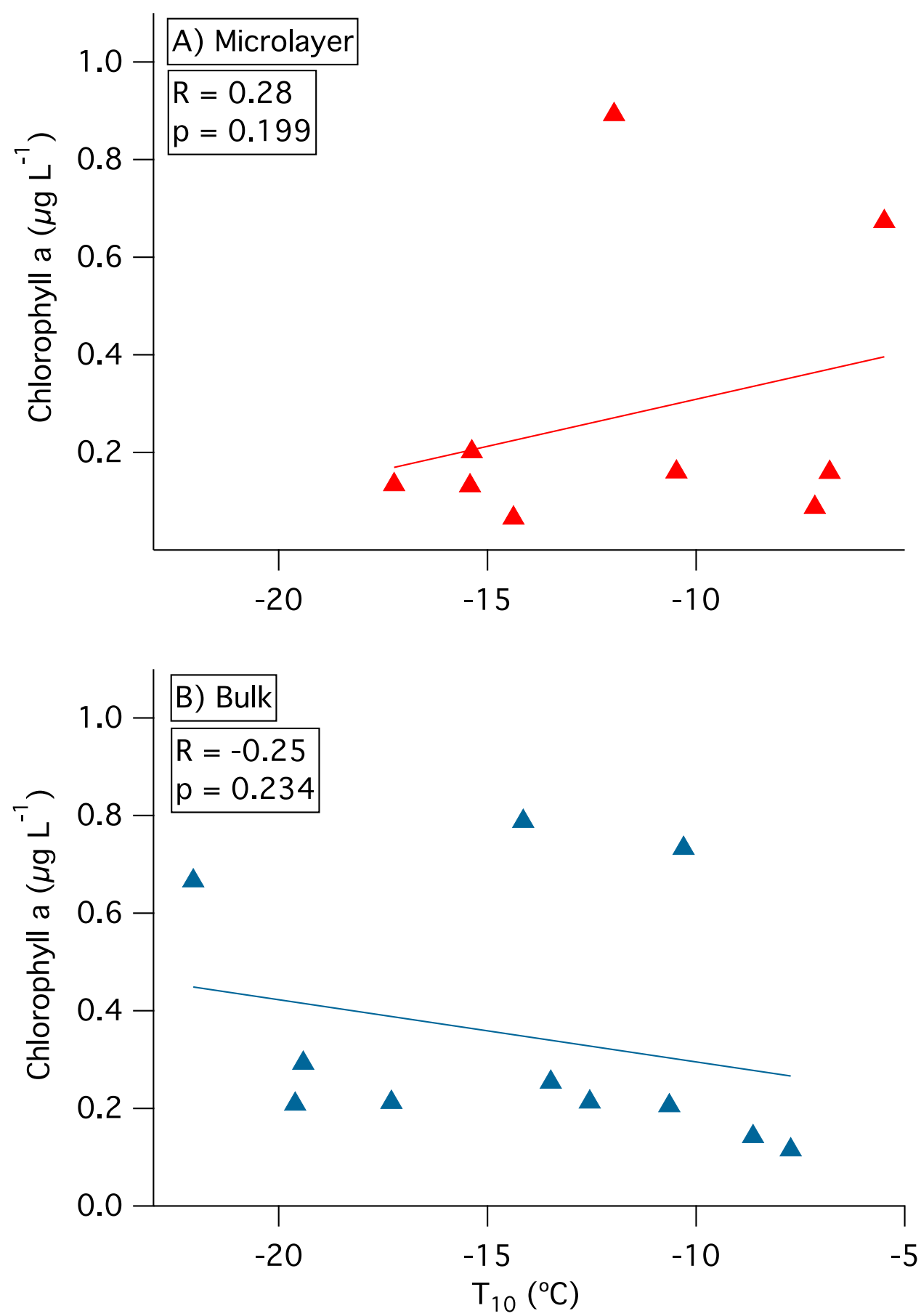

Figure S9. Relationship between our measured chlorophyll $a$ concentrations and the $\mathrm{T}_{10}$-values of microlayer and bulk seawater for 2016 . 


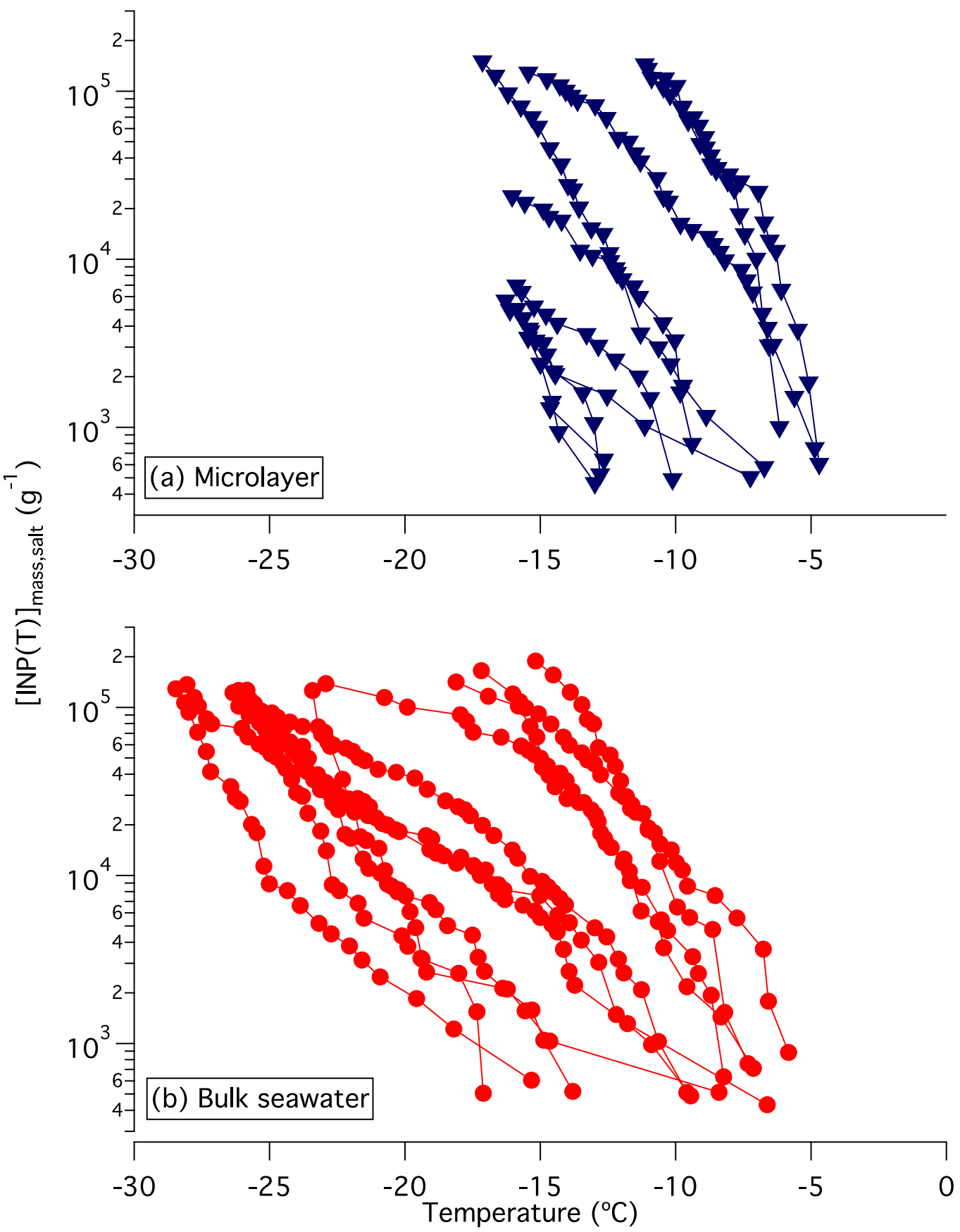

Figure S10. Plot of the concentration of INPs in the liquid per unit mass of sea salt, $[\operatorname{INP}(T)]_{\text {mass, salt }}$, as a function of temperature for (a) the microlayer, and (b) bulk seawater. 


\section{References}

Atkinson, M. J. and Bingman, C.: Elemental composition of commercial seasalts, J. Aquaric. Aquat. Sci., 8, 39-43 [online] Available from: http://www.rudyv.be/Aquarium/sels.pdf, 1997.

5 Burgers, T. M., Miller, L. A., Thomas, H., Else, B. G. T., Gosselin, M. and Papakyriakou, T.: Surface water $p \mathrm{CO}_{2}$ variations and sea-air $\mathrm{CO}_{2}$ fluxes during summer in the Eastern Canadian Arctic, J. Geophys. Res. Ocean., 122, 9663-9678, doi:10.1002/2017JC013250, 2017. 